\title{
Nutrient Intake, Dietary Patterns, and Anthropometric Indices of Children With ADHD in Comparison to Healthy Controls: A Case-Control Study
}

\section{Habibeh Salvat}

Ardabil University of Medical Sciences: Ardebil University of Medical Sciences

Mehriar Nader Mohammadi

Ardabil University of Medical Sciences: Ardebil University of Medical Sciences

\section{Parviz Molavi ( $\sim$ p.molavi@yahoo.com )}

Ardabil University of Medical Sciences: Ardebil University of Medical Sciences https://orcid.org/0000-00019879-3309

\section{Seyed Ali Mostafavi}

Tehran University of Medical Sciences

\section{Reza Rostami}

Tehran University: University of Tehran

\section{Mohammad Ali Salehinejad}

Ruhr University Bochum International Graduate School of Neuroscience

\section{Research}

Keywords: Attention-Deficit Hyperactivity Disorder (ADHD), lifestyle, Anthropometry, Nutrition.

Posted Date: March 30th, 2021

DOl: https://doi.org/10.21203/rs.3.rs-348588/v1

License: (c) (7) This work is licensed under a Creative Commons Attribution 4.0 International License. Read Full License 


\section{Abstract}

Objective: Poor health behaviors and indices are recently reported in Attention-deficit hyperactivity disorder (ADHD) lifestyle which might be relevant to the pathophysiology of this disorder. The objective of this case-control study was to assess the nutrient intake, dietary patterns, and anthropometric indices in ADHD children compared to normal peers.

Method. 100 children diagnosed with ADHD were included and compared to healthy, sex-matched normal children as the control group. Anthropometric indices, macronutrients, and micronutrients were measured and compared in both groups.

Results. ADHD children were significantly consuming more simple sugars, tea, ready-made meals but less protein, vitamin B1, vitamin B2, vitamin C, zinc and calcium compared to the control group. The body mass index (BMI) and waist circumference of ADHD children were significantly higher and were related to the severity and type of the disease.

Conclusion. Unhealthy lifestyle behavior is higher in ADHD which might warrants lifestyle intervention in this disorder.

\section{Background}

Attention-deficit and Hyperactivity Disorder (ADHD) is a common neurodevelopmental disorder of childhood and adolescence marked with core symptoms of inattention and hyperactivity [1] and cognitive dysfunctions (e.g., working memory, inhibition control) [2-4]. There is a consensus that the etiology of ADHD is heterogeneous and results from a complex interaction of pathophysiological and neurochemical systems with genetic phenotype. Other factors that contribute to the onset or sustainability of ADHD symptoms include psychosocial, environmental, and dietary factors [5-7]. The symptoms of inattention, impulsivity, and poor planning are suggested to contribute to poor health behaviors in ADHD patients [8]. Considering such diverse etiological factors, alternative or nonmedical treatments have been also proposed for the treatment or alleviation of ADHD symptoms including several kinds of dietary interventions [9]. In this line, however, there is still an urgent need for studies investigating dietary-related factors between ADHD children and their typically developing peers.

One factor related to dietary behavior is anthropometric indices. The word anthropometry consists of two parts: the anthropus means the human and the metric means measuring and is referred to as the measurement of human physical indices. One of the aims of anthropometric measurements is to examine the human body size and shape. In the developing population including children and adolescents, anthropometric measurements are applied as indices of growth and development [10]. Other anthropometric indices including body weight, height, body mass index (BMI), skinfold thickness, peripheral measurements and measuring fat mass, and muscle mass are usually used for nutritional evaluations [11].

Some of these anthropometric indices are investigated in children with ADHD. A study in this respect investigated the changes in body and hormone levels in children with ADHD and found that several indices are either lower or higher in children with ADHD when compared to typically-developing controls $[12,13]$. In another study, several differences in nutritional patterns were observed between children with ADHD and healthy controls. These differences were "not eating" breakfast, having a history of food allergies which contributed to ADHD symptoms 
severity, and higher intake of daily sugar in children with more severe ADHD symptoms [14]. Another related study reported a significantly lower weight and height of children with ADHD in comparison with their peers without ADHD [15]. In contrast, another study investigated obesity and overweight of ADHD children and found that 1017 years old boys and 10-17 years old girls with ADHD were significantly overweight than those in the control group [16]. ADHD as a potential risk factor for obesity and overweight is supported in another study that assessed the prevalence of obesity and overweight in children with ADHD [17].

The association of dietary behavior and ADHD symptoms is important for the well-being, general health, and development of children with ADHD, however, a limited number of studies exist in this respect. Moreover, although the above-mentioned studies provide some insight about nutrients and anthropometric indices in ADHD, no comprehensive investigation of indices is available. Finally, the mixed results from previous studies warrant further investigation in carefully-controlled case studies. Accordingly, in the present study we aimed to assess the dietary patterns, nutrient intake, and anthropometric indices in ADHD children as compared with normal children. Additionally, we assessed the anthropometric indices with regard to ADHD subtype and severity of symptoms.

\section{Methods}

\subsection{Study design population}

This study adopted a case-control design and performed on children aged 5-14 years old with and without ADHD. Sample size was determined based on previous similar works and using the Cochran formula and 200 children, including 100 children with ADHD (case group) and 100 typically developing controls (control group) were recruited. To reduce the confounding factors, two groups were matched for age and sex. Inclusion criteria for the ADHD group were (1) meet Diagnostic and Statistical Manual of Mental Disorders criteria (DSM-5) [1] for ADHD by consensus of the two experienced child psychiatrist, (2) no history of confounding medical, neurological, and psychiatric conditions, (3) and parent's scoring on the Conners Rating Scale [18]. Typically developing controls underwent the same evaluation and diagnostic procedure.

\subsection{Ethics}

All ethical requirements according to the declaration of Helsinki were met. The study protocol was described to parents and their children. We obtained the written informed consent form parents and oral assent from children before participation in the study. Ethical approval was obtained from the ethics committee review board of the Ardabil University of Medical Sciences (ethics code: IR.ARUMS.REC.1395.81).

\subsection{Study procedure}

Participants in the ADHD group were selected from the patients referred to the Fatemi Hospital of the correspondent university and healthy controls were age and sex-matched from kindergartens and schools during the year 2018. In both groups, children were screened for ADHD by a professional child psychiatrist according to the clinical interview based on the DSM-5 diagnostic criteria. The healthy control group was also interviewed for ruling out $A D H D$ and other neurodevelopmental disorders diagnosis. The severity of the disorder was furthermore assessed by the Conners questionnaire (parent form) [18]. Then dietary intake and anthropometric indices were assessed in both groups

\subsection{Anthropometric assessment}


In this study, anthropometric indices were measured by a trained physician. Anthropometric parameters were measured in the standard positions. Bodyweight was measured on a calibrated digital scale, to the nearest $0.1 \mathrm{Kg}$, for this purpose the subjects wore minimal clothes without shoes. Height was measured by an un-stretchable tape on a wall with a straight body position to the nearest $0.1 \mathrm{~cm}$. Waist and arm circumferences were measured by an un-stretchable tape to the nearest $0.1 \mathrm{~cm}$. Body mass index (BMI) was calculated by dividing weight (kg) to height squared (m2).

\subsection{Dietary assessment}

The children's nutritional information was collected by the Food Frequency Questionnaires (FFQ) [19]. The guideline for food portion sizes was delivered to parents and they were instructed to fill the FFQ for their children. The parents were asked to sort their children's average frequency consumption of each food item during the past year according to food portion sizes. Furthermore, a three-day food record was collected from participants. The parents should record all foods and beverages consumed by their children over three randomly selected days (two regular days and one weekend). The gathered data of dietary intake were analyzed by N4 software.

\subsection{Statistical analysis}

Data analysis was conducted using the SPSS-21 software package. Descriptive and inferential statistics (Student's t-test) were used to assess the difference of anthropometric differences including waist circumference $(\mathrm{cm})$, and BMI, and nutrients intake between the two groups of ADHD and control. The effect of ADHD subtype (3 values) and symptom severity on each anthropometric indices was also investigated using the univariate analysis of variance (ANOVA). The assumptions of homogeneity of variances and normal distribution were examined with Levene's test for homogeneity of variances and Shapiro-Wilk test of normality respectively.

\section{Results}

\subsection{Data overview}

The mean age of the ADHD children in the case group was $8.33 \pm 2.10$ years and the mean age of the control group was $8.26 \pm 2.00$ years. $72 \%$ of both groups were boys and the rest were girls. There was no significant difference between the groups in these demographic variables. Demographic information and the mean and standard deviation of age, weight, height, BMI, and other anthropometric indices are summarized in Table 1.

\subsection{Anthropometric indices}

In the case group, 28 children were diagnosed with predominantly hyperactive/impulsive type, 11 children with the predominantly inattentive type and 61 children were diagnosed with the combined type of ADHD. Also, in this group according to conners score $49 \%$ had mild, $37 \%$ had moderate and $14 \%$ had severe ADHD symptoms. Table 2 summarized the anthropometric indices in the children with ADHD subgrouped by type and severity of disease compared with the control group. There was a significant difference between ADHD children and their controls in the mean BMI $(p=0.012)$ and Waist Circumference $(p=0.039)$ (Table 1$)$. The results of ANOVA showed a significant main effect of ADHD type on the BMI and mean waist circumference (Table 2). Post hoc analysis showed a significantly higher mean BMI in the inattentive subtype compared to the hyperactive type. Similarly, the inattentive subtype had a significantly larger mean waist circumference compared to both hyperactive and combined subtypes. 


\subsection{Dietary pattern, micro-and micronutrients}

Table 3 compares the dietary consumption of macronutrients and micronutrients as well as some dietary habits between the case and control groups. This table indicates that the children in the ADHD group significantly consume more simple sugars $(p=0.007)$, tea $(p=0.006)$, and Ready-made meals $(p=0.002)$, and lower vitamins $\mathrm{B} 1, \mathrm{~B} 2, \mathrm{C}, \mathrm{Zn}$ and calcium than those in the control group.

\section{Discussion}

In this age and sex-matched case-control study, we compared nutrient intake, dietary patterns, and anthropometric indices of children with ADHD in comparison to healthy controls. The main findings of this study were that the levels of micronutrient intake such as vitamin C, vitamin B1, vitamin B2, calcium, zinc, and iron in children with ADHD were significantly lower compared to typically-developing peers.

With regard to nutrient intake and dietary patterns, although there was no significant difference between the total intake of carbohydrates and fat between the groups, consumption of simple sugars and tea was significantly higher and protein intake was significantly lower in children with ADHD compared to normal children. In the study by Ríos-Hernández et al (2017), (mean age: $9.3 \pm 2.8$ years; $56.7 \%$ boys) there was no significant difference in dietary caloric intakes and consumption of carbohydrate and fat between children with ADHD and normal children [20]. However, the level of simple sugars and caffeine consumption in children with ADHD was significantly higher. They also found that children with ADHD received less protein than healthy controls. It should be noted that although in their study consumption of micronutrients such as iron and zinc in the ADHD group was lower than the children in the control group, this difference was not statistically significant [20]. Furthermore, in a study by Azad Bakht et al. (2012) was found that in children with ADHD (mean age: $7 \pm 2$ years; $71 \%$ boys), carbohydrate intake is more than normal children. Also, vitamin C, vitamin B1, vitamin B2, calcium, zinc, and iron intakes in children with ADHD were significantly lower than healthy children; this finding is in line with our results [21]. Another relevant study in children with ADHD (mean age: $8.42 \pm 1.72$ years; $83.8 \%$ boys) found a series of negative correlations between ADHD symptoms and seafood and meat consumption $(p=0.006)$, dietary intake of zinc, protein, phosphorus, selenium, calcium, and riboflavin $(p=0.014)$, and the serum zinc level was negatively associated to $\operatorname{ADHD}(p=0.003)[22]$.

Regarding the anthropometric indices, a non-significant difference between the arm circumference of ADHD children and normal children [23]. Another cohort study found that ADHD would not be recognized as a risk factor for significant weight rise from its normal level [24]. In our study, however, the arm circumference of children with $A D H D$ was lower than that of normal children but this difference was not statistically significant. Different dietary patterns and socio-demographic or genetic factors may explain our novel results. In our study, in the ADHD group weight was slightly greater and height was slightly shorter compared to the control group. This caused the BMI to be significantly greater in the ADHD group. Also, abdominal circumference was significantly greater in the ADHD group. In line with our results, another study showed that the abdominal circumference and body fat percentage of non-medicated boys with ADHD was significantly higher but the height was shorter than normal peers [12]. Along with what we found in the present study, the mean height of the children in the case group (ADHD) in the study performed by Ríos Hernández et al. (2017) was shorter compared to the control group (136.5 $\pm 16.8 \mathrm{~cm}$ vs. $138.6 \pm 17.3 \mathrm{~cm}$; respectively). Also, the mean weight of children in the case group (ADHD) in their study was 
higher than the control group (38.1 $\pm 16.2 \mathrm{~kg}$ vs. $36.4 \pm 14.5 \mathrm{~kg}$; respectively) and there were no statistically significant differences between the two groups in these regards [20].

When it comes to height, results are also mixed. A study found that the height of non-medicated children with ADHD was significantly higher than normal children but after the beginning of pharmacotherapy, the growth velocity reduced so that those who remained on stimulant medication showed an annual growth rate about $20 \%$ less than what expected [25]. Moreover, in the two separate studies conducted by Ptacek et al. group, short height for age and sex was observed in non-medicated children with ADHD $[12,13]$. In the present study, although the height of children with ADHD was slightly lower than the control group, however, the difference was not significant even after considering the impact of ADHD subtype and disorder severity. The retardation in children with ADHD is increased by age. There is no significant difference in height at an earlier age compared to normal peers, however, over the time, due to the growth retardation, the height of ADHD children remains shorter than normal children. This gap in height growth does not induce a considerable risk compared with the WHO growth charts [26].

In this line, there is still controversy in various studies over the BMI difference between children with ADHD and their normal peers. In a relevant study, the BMI of children with ADHD was $19.6 \pm 3.4$ while it was $18 \pm 3.3$ in normal peers. Statistical analysis indicated that this difference was statistically significant [20]. Contrary to the above, the Mustillo et al. (2003) indicated no significant difference in BMI between children with ADHD and normal children [24]. In our study, in line with most studies, children with ADHD were more likely to have upper BMI than normal children. With respect to waist circumference, a study showed that children with ADHD who received no medication had significantly higher waist circumference than normal children [12]. On the other hand, the same researcher showed a significant difference in growth between children with ADHD that did not receive any medications and normal children when the sample size was doubles [13]. The synthesis of the results of this work by the researcher reveals that the involvement of some anthropometric indices, and reduction in growth velocity in children with ADHD, can be one of the clinical manifestations of the disease itself and not due to the complications of medications.

Finally, we observed differences in eating behavior between ADHD children and healthy controls. Children with ADHD had significantly higher waist circumference which is the indicator of fat tissue accumulation in the abdomen. The cause of weight gain and fat accumulation in these children may be due to the association between impulsive behavior and loss of control in eating [27]. Also, according to another study, aggression and lack of attention in these children increase their appetite for food [28]. Besides, improper food patterns lead to an increase in body weight. According to the researches performed on food patterns in children with ADHD, the results indicated a high consumption of simple sugars, ready-made meals and a high-carbohydrate diet [29]. On the other hand, defects in dopaminergic pathways can be effective both in ADHD and obesity. Evidence is found in people with $A D H D$ and obese people that genetic changes may involve in the dopaminergic regulation pathways and related systems, including melanocortin, which play role in both ADHD and obesity. Due to the low levels of dopamine neurotransmitters, serotonin, and norepinephrine in the brain that lead to mood disorders and reduced desire to engage in physical activity, these children and adolescents are prone to overweight and obesity [30]. In children with ADHD, moving skills, executive functioning, and physical fitness are significantly lower compared to normal children who may contribute to obesity [31]. Some limitations should be considered in our study. Despite the instructions and guidelines delivered to parents, studied food pattern may have missed some items, including snacks used in schools, which may children provide from school buffet. Furthermore, parents' awareness of ADHD may affect the children's dietary patterns.

Page 6/16 


\section{Conclusion}

Children with ADHD have higher waist circumference and BMI than healthy children, and this difference was related to the severity of the disease and its type. The BMI and waist circumference in children with mild ADHD and mostly attention-deficit type of ADHD was significantly higher than the control group. Children with ADHD consume more simple sugars, tea, and ready-made foods but lower vitamin B1, vitamin B2, vitamin C, zinc and calcium compared with their normal control peers.

\section{Declarations}

\section{Ethics approval and consent to participate}

The protocol was conducted in accordance with the latest version of the Declaration of Helsinki and was approved by the Institutional Review Board and ethical committee at the xxx University of Medical Sciences. We obtained the written informed consent form the parents and oral assent from children before participation in the study. The ethical approval was obtained from the ethics committee review board in the Ardabil University of Medical Sciences (ethics code: IR.ARUMS.REC.1395.81).

\section{Consent for publication}

All participants' parents were instructed about experimental procedures and gave their written informed consent.

\section{Availability of data and materials}

The datasets used and/or analyzed during the current study are available from the corresponding author on reasonable request.

\section{Competing interests}

MAN is a member of the Scientific Advisory Board of Neuroelectrics. All other authors declare no competing interests

\section{Funding}

None

\section{Authors' contributions}

PM \& MN conceived the study. HS \& MN collected the data and interpreted the data. MN and MAS wrote the first draft. MAS, SAM \& RR revised and reviewed. All authors read and approved the final manuscript.

\section{Acknowledgments}

The researchers announced their gratitude to all parents and children who participated in this study, as well as to the honorable authorities of Fatemi Hospital, Child Psychiatry division., who are fully committed to this study.

\section{Authors' information}


Department of Psychiatry, Fatemi Hospital, School of Medicine, Ardabil University of Medical Sciences, Ardabil, Iran

\section{Mehriar Nader Mohammadi}

Department of Psychiatry, Fatemi Hospital, School of Medicine, Ardabil University of Medical Sciences, Ardabil, Iran

\section{Parviz Molavi}

Department of Psychiatry, Fatemi Hospital, School of Medicine, Ardabil University of Medical Sciences, Ardabil, Iran

\section{Seyed Ali Mostafavi}

Department of Psychiatry, Tehran University of Medical Sciences, Tehran, Iran

\section{Reza Rostami}

Department of Psychology, University of Tehran, Tehran, Iran

\section{Mohammad Ali Salehinejad}

Leibniz Research Centre for Working Environment and Human Factors, Department of Psychology and Neurosciences, Dortmund, Germany \& Ruhr-University Bochum, International Graduate School of Neuroscience, Bochum, Germany

\section{References}

1. American Psychiatric Association: Diagnostic and statistical manual of mental disorders (DSM-5®): American Psychiatric Pub; 2013.

2. Doernberg E, Hollander E: Neurodevelopmental Disorders (ASD and ADHD): DSM-5, ICD-10, and ICD-11. CNS spectrums 2016, 21(4):295-299.

3. Mohammadi MR, Ahmadi N, Khaleghi A, Mostafavi SA, Kamali K, Rahgozar M, Ahmadi A, Hooshyari Z, Alavi SS, Molavi P: Prevalence and correlates of psychiatric disorders in a national survey of Iranian children and adolescents. Iranian journal of psychiatry 2019, 14(1):1.

4. Molavi P, Nadermohammadi M, Ghojehbeiglou HS, Vicario CM, Nitsche MA, Salehinejad MA: Cognitive correlates of ADHD subtypes and its association with self-esteem: A quantitative difference. BMC Psychiatry 2020.

5. Mohammadi MR, Mostafavi SA, Hooshyari Z, Khaleghi A, Ahmadi N, Molavi P, Armani Kian A, Safavi P, Delpisheh A, Talepasand S: Prevalence, correlates and comorbidities of feeding and eating disorders in a nationally representative sample of Iranian children and adolescents. Int J Eat Disord 2019.

6. Molavi P, Mikaeili N, Ghaseminejad MA, Kazemi Z, Pourdonya M: Social Anxiety and Benign and Toxic Online Self-Disclosures: An Investigation Into the Role of Rejection Sensitivity, Self-Regulation, and Internet Addiction in College Students. The Journal of nervous and mental disease 2018, 206(8):598-605. 
7. Mostafavi S-A, Mohammadi MR, Hosseinzadeh P, Eshraghian MR, Akhondzadeh S, Hosseinzadeh-Attar MJ, Ranjbar E, Kooshesh SM-A, Keshavarz S-A: Dietary intake, growth and development of children with ADHD in a randomized clinical trial of Ritalin and Melatonin co-administration: Through circadian cycle modification or appetite enhancement? Iranian journal of psychiatry 2012, 7(3):114.

8. Holton KF, Nigg JT: The Association of Lifestyle Factors and ADHD in Children. Journal of Attention Disorders 2016, 0(0):1087054716646452.

9. Nigg JT, Holton K: Restriction and Elimination Diets in ADHD Treatment. Child Adolesc Psychiatr Clin N Am 2014, 23(4):937-953.

10. Utkualp N, Ercan I: Anthropometric measurements usage in medical sciences. BioMed research international 2015, 2015.

11. Shils ME, Shike M: Modern nutrition in health and disease: Lippincott Williams \& Wilkins; 2006.

12. Ptacek R, Kuzelova H, Paclt I, Zukov I, Fischer S: Anthropometric changes in non-medicated ADHD boys. Neuro Endocrinol Lett 2009, 30(3):377-381.

13. Ptáček R, Kuželová H, Paclt I, Žukov I, Fischer S: Somatic and endocrinological changes in non medicated ADHD children. Prague Med Rep 2009, 110(1):25-34.

14. Amani R, Khajeh Mougahi N: Comparison between nutritional pattern of school children with attention deficit hyperactivity disorder and that of normal subjects. Razi Journal of Medical Sciences 2005, 12(45):37-42.

15. Güngör S, Celiloğlu ÖS, Raif SG, Özcan ÖÖ, Selimoğlu MA: Malnutrition and obesity in children with ADHD. Journal of attention disorders 2016, 20(8):647-652.

16. Fliers EA, Buitelaar JK, Maras A, Bul K, Höhle E, Faraone SV, Franke B, Rommelse NN: ADHD is a risk factor for overweight and obesity in children. Journal of developmental and behavioral pediatrics: JDBP 2013, 34(8).

17. Yang R, Mao S, Zhang S, Li R, Zhao Z: Prevalence of obesity and overweight among Chinese children with attention deficit hyperactivity disorder: a survey in Zhejiang Province, China. BMC psychiatry 2013, 13(1):133.

18. Conners CK, Sitarenios G, Parker JDA, Epstein JN: The Revised Conners' Parent Rating Scale (CPRS-R): Factor Structure, Reliability, and Criterion Validity. Journal of Abnormal Child Psychology 1998, 26(4):257-268.

19. Cade J, Thompson R, Burley V, Warm D: Development, validation and utilisation of food-frequency questionnaires-a review. Public Health Nutr 2002, 5(4):567-587.

20. Ríos-Hernández A, Alda JA, Farran-Codina A, Ferreira-García E, Izquierdo-Pulido M: The Mediterranean diet and ADHD in children and adolescents. Pediatrics 2017, 139(2):e20162027.

21. Azadbakht L, Esmaillzadeh A: Dietary patterns and attention deficit hyperactivity disorder among Iranian children. Nutrition 2012, 28(3):242-249.

22. Zhou F, Wu F, Zou S, Chen Y, Feng C, Fan G: Dietary, nutrient patterns and blood essential elements in Chinese children with ADHD. Nutrients 2016, 8(6):352.

23. Ptacek R, Kuzelova H, Paclt I, Zukov I, Fischer S: ADHD and growth: anthropometric changes in medicated and non-medicated ADHD boys. Med Sci Monit 2009, 15(12):CR595-CR599.

24. Mustillo S, Worthman C, Erkanli A, Keeler G, Angold A, Costello EJ: Obesity and psychiatric disorder: developmental trajectories. Pediatrics 2003, 111(4):851-859.

25. Swanson J, Greenhill L, Wigal T, Kollins S, Stehli A, Davies M, Chuang S, Vitiello B, Skrobala A, Posner K: Stimulant-related reductions of growth rates in the PATS. Journal of the American Academy of Child \& Adolescent Psychiatry 2006, 45(11):1304-1313. 
26. Marcdante K, Kliegman R: Nelson Essentials of Pediatrics, 8 edn; 2018.

27. Mikami AY, Hinshaw SP, Patterson KA, Lee JC: Eating pathology among adolescent girls with attentiondeficit/hyperactivity disorder. Journal of abnormal psychology 2008, 117(1):225.

28. Bazar KA, Yun AJ, Lee PY, Daniel SM, Doux JD: Obesity and ADHD may represent different manifestations of a common environmental oversampling syndrome: a model for revealing mechanistic overlap among cognitive, metabolic, and inflammatory disorders. Med Hypotheses 2006, 66(2):263-269.

29. Cortese S, Angriman M, Maffeis C, Isnard P, Konofal E, Lecendreux M, Purper-Ouakil D, Vincenzi B, Bernardina BD, Mouren M-C: Attention-deficit/hyperactivity disorder (ADHD) and obesity: a systematic review of the literature. Crit Rev Food Sci Nutr 2008, 48(6):524-537.

30. Davis C, Levitan RD, Kaplan AS, Carter J, Reid C, Curtis C, Patte K, Hwang R, Kennedy JL: Reward sensitivity and the D2 dopamine receptor gene: A case-control study of binge eating disorder. Progress in NeuroPsychopharmacology and Biological Psychiatry 2008, 32(3):620-628.

31. Pan C-Y, Chang Y-K, Tsai C-L, Chu C-H, Cheng Y-W, Sung M-C: Effects of physical activity intervention on motor proficiency and physical fitness in children with ADHD: An exploratory study. Journal of attention disorders 2017, 21(9):783-795.

\section{Tables}


Table 1

Comparison of different parameters of children in the case and control groups

\begin{tabular}{|c|c|c|c|c|}
\hline General category & Parameter & Case group & Control group & group $P$-value \\
\hline \multirow[t]{3}{*}{ Age (Year) } & Mean \pm SD & $8.33 \pm 2.08$ & $8.26 \pm 2.08$ & NS \\
\hline & Min & 5 & 5 & \\
\hline & Max & 13 & 13 & \\
\hline \multirow[t]{2}{*}{ Sex } & Male & 72(72\%) & 72(72\%) & NS \\
\hline & female & $28(28 \%)$ & $28(28 \%)$ & \\
\hline \multirow[t]{3}{*}{ Weight (kg) } & Mean & $25.69 \pm 5.96$ & $25.05 \pm 6.60$ & NS \\
\hline & Min & 14 & 11.50 & \\
\hline & Max & 42.5 & 48.50 & \\
\hline \multirow[t]{3}{*}{ Height (cm) } & Mean & $122.68 \pm 12.07$ & $123.35 \pm 12.43$ & NS \\
\hline & Min & 92 & 97 & \\
\hline & Max & 152 & 151 & \\
\hline \multirow[t]{3}{*}{ BMI (kg/Sq. M) } & Mean & $16.99 \pm 2.17$ & $16.16 \pm 1.90$ & $0.012^{*}$ \\
\hline & Min & 13.20 & 11.39 & \\
\hline & Max & 28.10 & 26.04 & \\
\hline Waist & Mean & $60.96 \pm 8.88$ & $58.38 \pm 8.69$ & $0.039^{*}$ \\
\hline \multirow[t]{2}{*}{ Circumference (cm) } & Min & 13.2 & 41 & \\
\hline & $\operatorname{Max}$ & 28.1 & 78 & \\
\hline Arm & Mean & $22.61 \pm 4.51$ & $21.51 \pm 4.56$ & NS \\
\hline \multirow[t]{2}{*}{ Circumference (cm) } & Min & 13 & 12.50 & \\
\hline & Max & 40 & 34.00 & \\
\hline
\end{tabular}


Table 2

Anthropometric indices in the children with ADHD subgrouped by type and severity of disease in comparison with the control group

\begin{tabular}{|c|c|c|c|c|c|c|c|c|}
\hline General group & $\begin{array}{l}\text { Type } \\
\text { and } \\
\text { severity } \\
\text { of } \\
\text { disorder }\end{array}$ & parameters & number & Mean & $\begin{array}{l}\text { Standard } \\
\text { deviation }\end{array}$ & $F$ & $\begin{array}{l}p- \\
\text { values }\end{array}$ & $\begin{array}{l}\text { Pairwise } \\
\text { comparisons }\end{array}$ \\
\hline \multirow[t]{8}{*}{$\begin{array}{l}\text { Mean weight } \\
(\mathrm{kg})\end{array}$} & \multirow[t]{4}{*}{$\begin{array}{l}\text { Type of } \\
\text { disorder }\end{array}$} & $\begin{array}{l}\text { Control } \\
\text { group }\end{array}$ & 100 & 25.05 & 6.60 & \multirow[t]{4}{*}{1.342} & \multirow[t]{4}{*}{0.262} & \multirow[t]{4}{*}{ na } \\
\hline & & $\begin{array}{l}\text { Mostly } \\
\text { hyperactive }\end{array}$ & 28 & 24.80 & 6.25 & & & \\
\hline & & $\begin{array}{l}\text { Mostly } \\
\text { attention } \\
\text { deficit }\end{array}$ & 11 & 28.90 & 6.80 & & & \\
\hline & & Combined & 61 & 25.51 & 5.58 & & & \\
\hline & \multirow{4}{*}{$\begin{array}{l}\text { The } \\
\text { severity } \\
\text { of } \\
\text { disorder }\end{array}$} & $\begin{array}{l}\text { Control } \\
\text { group }\end{array}$ & 100 & 25.05 & 6.60 & \multirow[t]{4}{*}{0.731} & \multirow[t]{4}{*}{0.535} & \multirow[t]{4}{*}{ na } \\
\hline & & mild & 49 & 25.63 & 6.55 & & & \\
\hline & & moderate & 37 & 26.44 & 5.67 & & & \\
\hline & & severe & 14 & 23.89 & 4.24 & & & \\
\hline \multirow[t]{6}{*}{$\begin{array}{l}\text { Mean height } \\
\text { (cm) }\end{array}$} & \multirow[t]{4}{*}{$\begin{array}{l}\text { Type of } \\
\text { disorder }\end{array}$} & $\begin{array}{l}\text { Control } \\
\text { group }\end{array}$ & 100 & 123.35 & 12.43 & \multirow[t]{4}{*}{0.827} & \multirow[t]{4}{*}{0.480} & \multirow[t]{4}{*}{ na } \\
\hline & & $\begin{array}{l}\text { Mostly } \\
\text { hyperactive }\end{array}$ & 28 & 122.00 & 12.67 & & & \\
\hline & & $\begin{array}{l}\text { Mostly } \\
\text { attention } \\
\text { deficit }\end{array}$ & 11 & 128.00 & 10.16 & & & \\
\hline & & Combined & 61 & 122.03 & 12.04 & & & \\
\hline & \multirow{2}{*}{$\begin{array}{l}\text { The } \\
\text { severity } \\
\text { of } \\
\text { disorder }\end{array}$} & $\begin{array}{l}\text { Control } \\
\text { group }\end{array}$ & 100 & 123.35 & 12.43 & \multirow[t]{2}{*}{1.514} & \multirow[t]{2}{*}{0.212} & \multirow[t]{2}{*}{ na } \\
\hline & & mild & 49 & 121.42 & 13.19 & & & \\
\hline
\end{tabular}




\begin{tabular}{|c|c|c|c|c|c|c|c|c|}
\hline \multirow[t]{3}{*}{ General group } & $\begin{array}{l}\text { Type } \\
\text { and } \\
\text { severity } \\
\text { of } \\
\text { disorder }\end{array}$ & parameters & number & Mean & $\begin{array}{l}\text { Standard } \\
\text { deviation }\end{array}$ & $\mathbf{F}$ & $\begin{array}{l}\text { p- } \\
\text { values }\end{array}$ & $\begin{array}{l}\text { Pairwise } \\
\text { comparisons }\end{array}$ \\
\hline & & moderate & 37 & 125.81 & 11.00 & & & \\
\hline & & severe & 14 & 118.78 & 9.05 & & & \\
\hline \multirow[t]{8}{*}{ Mean BMI } & \multirow[t]{4}{*}{$\begin{array}{l}\text { Type of } \\
\text { disorder }\end{array}$} & $\begin{array}{l}\text { Control } \\
\text { group }\end{array}$ & 100 & 16.16 & 1.90 & \multirow[t]{4}{*}{2.998} & \multirow[t]{4}{*}{$0.032^{*}$} & \multirow[t]{2}{*}{ na } \\
\hline & & $\begin{array}{l}\text { Mostly } \\
\text { hyperactive }\end{array}$ & 28 & 16.38 & 1.28 & & & \\
\hline & & $\begin{array}{l}\text { Mostly } \\
\text { attention } \\
\text { deficit }\end{array}$ & 11 & 17.35 & 1.80 & & & $A D>H D$ \\
\hline & & Combined & 61 & 17.04 & 2.52 & & & na \\
\hline & \multirow{4}{*}{$\begin{array}{l}\text { The } \\
\text { severity } \\
\text { of } \\
\text { disorder }\end{array}$} & $\begin{array}{l}\text { Control } \\
\text { group }\end{array}$ & 100 & 16.16 & 1.90 & \multirow[t]{4}{*}{2.990} & \multirow[t]{4}{*}{$0.032^{*}$} & \\
\hline & & mild & 49 & 17.20 & 2.82 & & & $\begin{array}{l}\text { mild > } \\
\text { control, } \\
\text { moderate }\end{array}$ \\
\hline & & moderate & 37 & 16.49 & 1.18 & & & \multirow[t]{2}{*}{ na } \\
\hline & & severe & 14 & 16.84 & 1.38 & & & \\
\hline \multirow{6}{*}{$\begin{array}{l}\text { Mean waist } \\
\text { circumference } \\
\text { (cm) }\end{array}$} & \multirow{4}{*}{$\begin{array}{l}\text { Type of } \\
\text { disorder }\end{array}$} & $\begin{array}{l}\text { Control } \\
\text { group }\end{array}$ & 100 & 803.82 & 96.73 & \multirow[t]{4}{*}{3.144} & \multirow[t]{4}{*}{$0.016^{*}$} & \multirow[t]{3}{*}{ na } \\
\hline & & $\begin{array}{l}\text { Mostly } \\
\text { hyperactive }\end{array}$ & 28 & 734.46 & 75.77 & & & \\
\hline & & $\begin{array}{l}\text { Mostly } \\
\text { attention } \\
\text { deficit }\end{array}$ & 11 & 804.09 & 82.69 & & & \\
\hline & & Combined & 61 & 780.00 & 139.79 & & & $A D / H D>H D$ \\
\hline & $\begin{array}{l}\text { The } \\
\text { severity } \\
\text { of }\end{array}$ & $\begin{array}{l}\text { Control } \\
\text { group }\end{array}$ & 100 & 803.82 & 96.73 & 1.670 & 0.175 & na \\
\hline & disorder & 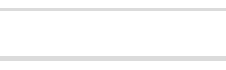 & & & & & & \\
\hline
\end{tabular}




\begin{tabular}{|c|c|c|c|c|c|c|c|c|}
\hline General group & $\begin{array}{l}\text { Type } \\
\text { and } \\
\text { severity } \\
\text { of } \\
\text { disorder }\end{array}$ & parameters & number & Mean & $\begin{array}{l}\text { Standard } \\
\text { deviation }\end{array}$ & $F$ & $\begin{array}{l}\mathrm{p}- \\
\text { values }\end{array}$ & $\begin{array}{l}\text { Pairwise } \\
\text { comparisons }\end{array}$ \\
\hline & \multirow{7}{*}{$\begin{array}{l}\text { Type of } \\
\text { disorder }\end{array}$} & mild & 49 & 764.89 & 145.49 & & & \\
\hline & & moderate & 37 & 777.02 & 96.64 & & & \\
\hline & & severe & 14 & 768.57 & 85.40 & & & \\
\hline \multirow{8}{*}{$\begin{array}{l}\text { Mean arm } \\
\text { circumference } \\
\text { (cm) }\end{array}$} & & $\begin{array}{l}\text { Control } \\
\text { group }\end{array}$ & 100 & 21.51 & 4.55 & 2.341 & 0.075 & na \\
\hline & & $\begin{array}{l}\text { Mostly } \\
\text { hyperactive }\end{array}$ & 28 & 21.83 & 4.46 & & & \\
\hline & & $\begin{array}{l}\text { Mostly } \\
\text { attention } \\
\text { deficit }\end{array}$ & 11 & 25.045 & 4.17 & & & \\
\hline & & Combined & 61 & 22.53 & 4.50 & & & \\
\hline & $\begin{array}{l}\text { The } \\
\text { severity } \\
\text { of }\end{array}$ & $\begin{array}{l}\text { Control } \\
\text { group }\end{array}$ & 100 & 21.51 & 4.56 & 1.311 & 0.272 & na \\
\hline & \multirow[t]{3}{*}{ disorder } & mild & 49 & 23.06 & 4.67 & & & \\
\hline & & moderate & 37 & 22.28 & 4.58 & & & \\
\hline & & severe & 14 & 21.92 & 3.80 & & & \\
\hline
\end{tabular}

Table-3 Comparison of macronutrients and micronutrients as well as some dietary habits in case and control groups 


\begin{tabular}{|c|c|c|c|}
\hline Food & Case group & Control group & P-value \\
\hline $\begin{array}{l}\text { Carbohydrate (energy } \\
\text { percentage) }\end{array}$ & $60.48 \pm 3.05$ & $59.86 \pm 2.71$ & NS \\
\hline Fat (energy percentage) & $29.03 \pm 3.33$ & $28.5 \pm 2.15$ & NS \\
\hline Protein (energy percentage) & $10.49 \pm 2.47$ & $11.64 \pm 2.12$ & 0.001 * \\
\hline Simple sugars (g) & $44.66 \pm 7.41$ & $41.3 \pm 8.93$ & 0.007 * \\
\hline Tea (glasses) & $2.4 \pm 0.9$ & $1.9 \pm 0.5$ & 0.006 * \\
\hline $\begin{array}{l}\text { Ready-made meal (weekly } \\
\text { turn) }\end{array}$ & $1.44 \pm 0.72$ & $0.83 \pm 0.61$ & 0.002 * \\
\hline Vitamin A (mg) & $512.1 \pm 100.1$ & $524.23 \pm 98.7$ & NS \\
\hline Vitamin E (mg) & $7.4 \pm 2.5$ & $7.8 \pm 1.9$ & NS \\
\hline Vitamin B1 (mg) & $0.82 \pm 0.17$ & $0.94 \pm 0.18$ & 0.001 * \\
\hline Vitamin B2 (mg) & $0.47 \pm 0.1$ & $0.51 \pm 0.09$ & 0.004 * \\
\hline Vitamin B3 (mg) & $14.53 \pm 8.1$ & $14.8 \pm 8.3$ & NS \\
\hline Vitamin B5 (mg) & $2.1 \pm 0.82$ & $2.2 \pm 0.91$ & NS \\
\hline Vitamin B6 (mg) & $0.92 \pm 0.68$ & $1.01 \pm 0.73$ & NS \\
\hline Vitamin B12 (mg) & $2.1 \pm 1.15$ & $2.2 \pm 1.12$ & NS \\
\hline Vitamin C (mg) & $82.43 \pm 17.51$ & $92.26 \pm 17.52$ & 0.001 * \\
\hline Iron (mg) & $9.32 \pm 1.1$ & $9.6 \pm 0.99$ & NS \\
\hline Selenium (micrograms) & $24.05 \pm 9.6$ & $25.19 \pm 13.8$ & NS \\
\hline Zinc (mg) & $2.91 \pm 0.55$ & $3.06 \pm 0.51$ & $0.044^{\star}$ \\
\hline Calcium (mg) & $769.9 \pm 121.03$ & $803.82 \pm 96.73$ & $0.030^{\star}$ \\
\hline Magnesium (mg) & $82.05 \pm 26.34$ & $85.18 \pm 25.09$ & NS \\
\hline
\end{tabular}

* T-test is statistically significant at $p<0.5$. 


\section{a}

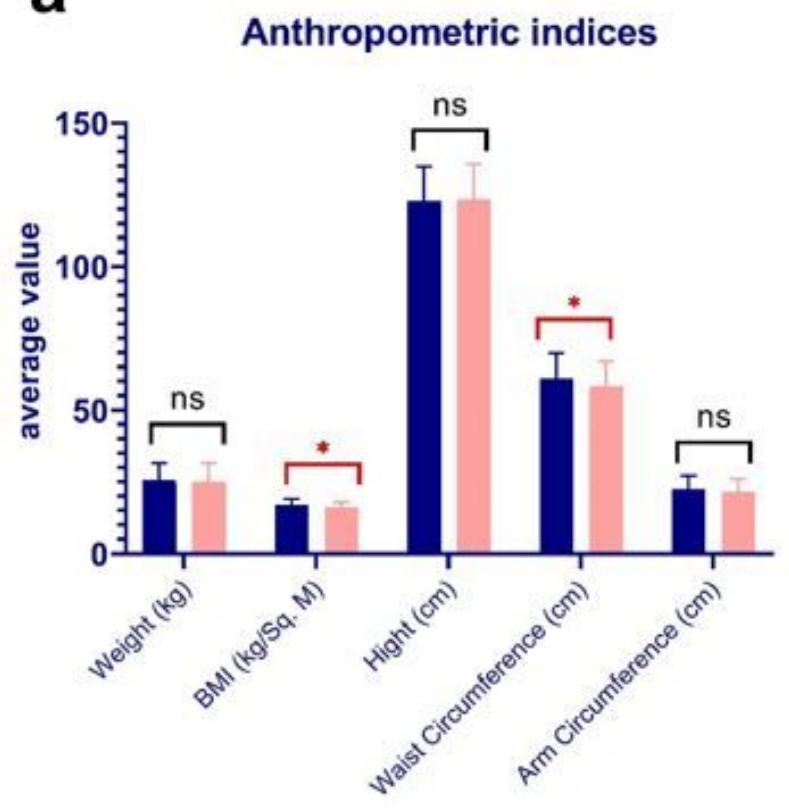

C

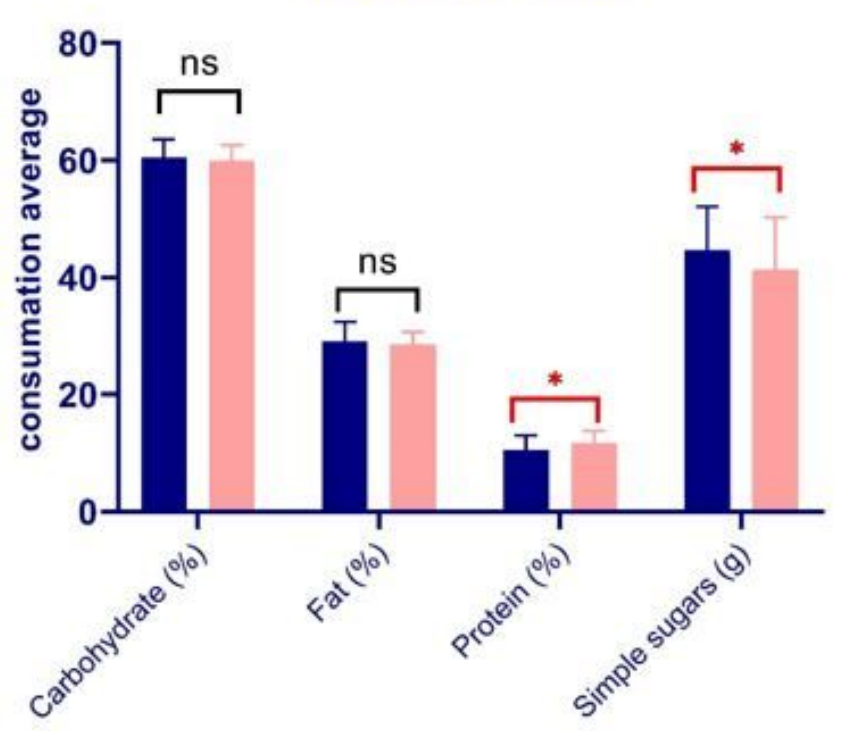

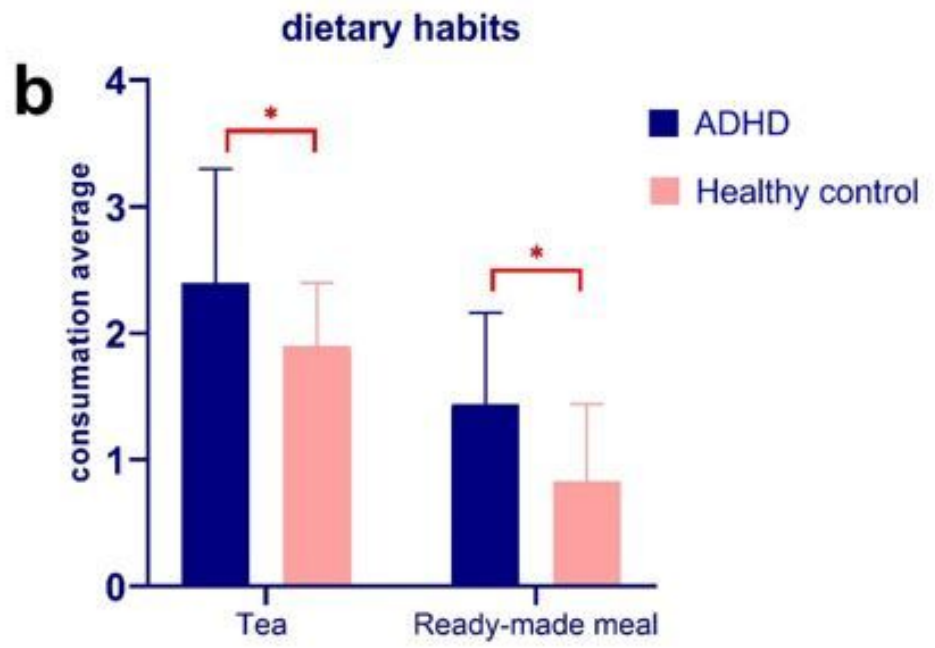

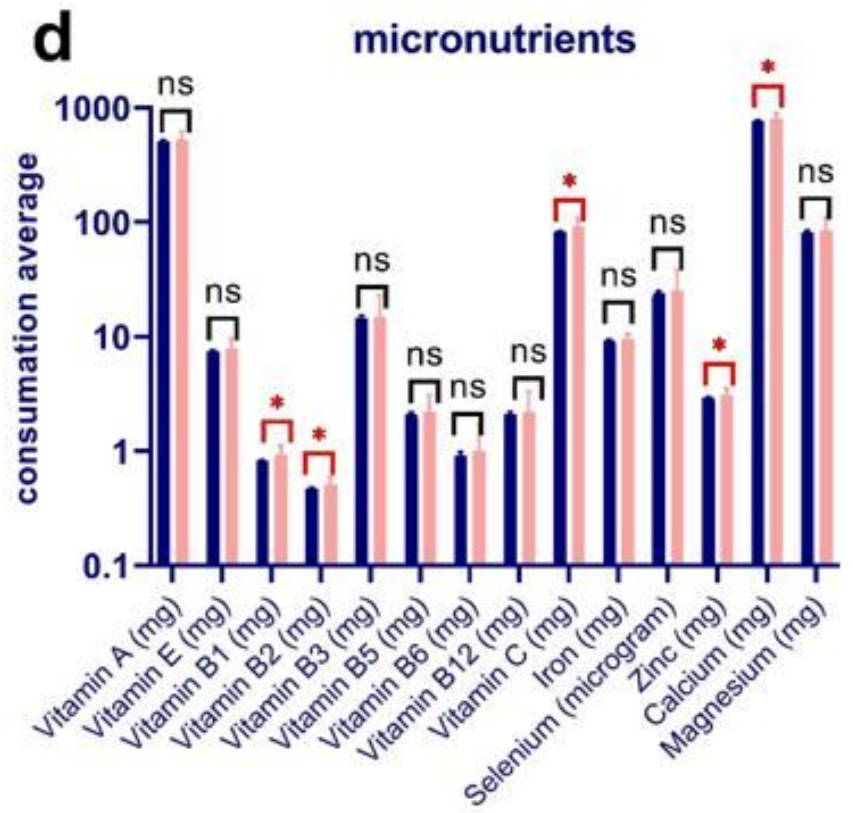

Figure 1

The mean values of anthropometric indices (a), dietary habits (b), macronutrients (c) and micronutrients (d) in ADHD children compared to healthy controls. Note: $n s=$ nonsignificant; asterisk = significant difference 